\title{
AZ ENERGIAFÜGGŐSÉG VIZSGÁLATA A MEGÚJULÓ ENERGIAFORRÁSOK ÉS AZ ÜVEGHÁZHATÁSÚ GÁZKIBOCSÁTÁS TÜKRÉBEN AZ EU-28 ORSZÁGAIBAN
}

EXAMINATION OF THE ENERGY DEPENDENCY IN THE MIRROR OF THE RENEWABLE ENERGY SOURCES AND THE GREENHOUSE GAS EMISSION

\author{
D. Németh Zsuzsanna ${ }^{1}$, Székely László ${ }^{2}$ \\ ${ }^{1} \mathrm{Ph} . \mathrm{D}$. hallgató, ${ }^{2}$ egyetemi docens \\ ${ }^{1}$ Szent István Egyetem Gazdálkodás és Szervezéstudományok Doktori Iskola, \\ ${ }^{2}$ Szent István Egyetem Gépészmérnöki Kar Környezetipari Rendszerek Intézet, \\ Matematika Tanszék \\ E-mail: 1d.nemeth.zs@gmail.com, ${ }^{2}$ szekely.laszlo@gek.szie.hu
}

\section{Összefoglalás}

A népesség növekedésével párhuzamosan, valamint az emberi tevékenységek változatosságát és intenzitásuk növekedését követően az emelkedő energiaigény maga után vonta az üvegházhatású gázok jelentős növekedését, mely a klímaváltozás első számú okaként ismert. A hagyományos energiák növekvő felhasználása mellett a jövőben a megújuló energiák növekedése is várható. A tanulmány a megújuló energiaforrások kapcsolatait vizsgálja az üvegházhatású gázkibocsátással valamint az energiafüggőséggel, a 2004-2014-ig tartó időszakban.

\begin{abstract}
Parallel with the increasing population, the diversity and intensity of human activities caused the growth of energy demand which implied the significant increase of the emission of greenhouse gasses, what is known as the main reason of climate change. In the future the renewable energies' and the traditional energies' utilisation is expected to grow. That is why the study considers the connection of the renewable energy sources with the greenhouse gas emission as well as energy dependency, in the period of years 2004 to 2014.
\end{abstract}

Kulcsszavak: megújuló energiaforrások, üvegházhatású gázkibocsátás, energiafüggőség, klaszteranalízis, EU-28

JEL besorolás: $\mathrm{O} 13$

LCC: S589.75-589.76

\section{Bevezetés}

A globális felmelegedéshez nagyban hozzájáruló üvegházhatású gázból, a szén-dioxidból az emberiség minden évben közel negyven millió tonna mennyiséget juttat a légkörbe. A légköri szén-dioxid koncentrációjának folyamatos növekedése következtében egyre nagyobb igény és érdeklődés mutatkozik a szén-dioxid mennyiségének változásának és hatásainak követésére.

A légköri szén-dioxid koncentrációjának folyamatos növekedése a lakosság növekvő energiaigényével is kapcsolatban áll. A növekvő energiafogyasztást a népesség növekedése is generálja, amely egyre nagyobb igényeket támaszt az élelmezés, lakhatás, közlekedés, humánegészségügy stb. területén. A Föld népességének rohamos növekedésével meghatározó mértékben nő az élelmiszerek iránti igény is. Az élet minőségének három - vitathatatlanul 
legfontosabb - alapjellemzője: a megfelelő mennyiségü és minőségü élelmiszer, a jó minőségü, „tiszta” víz és a kellemes környezet (Várallyay, 2010).

Bár a hagyományos energiahordozók felhasználásának ugrásszerü növekedése az ipari forradalom idejére vezethető vissza, az elmúlt közel fél évszázadban tapasztalható népességrobbanás a müvelésbe vont mezőgazdasági területek kiterjedésében is jelentős változást eredményezett. A világ összes területének, valamint a megmüvelt területek és a világ népességének változását 1970-2014 közötti időszakban az 1. táblázat szemlélteti.

\section{1. táblázat: A világ összes területének, a megmúvelt területek és a világ népességének változása 1970-2014 között}

\begin{tabular}{|c|c|c|r|r|r|r|}
\hline Év & $\begin{array}{c}\text { Világ összes } \\
\text { terület } \\
\mathbf{( k m}^{\mathbf{2}} \mathbf{)}\end{array}$ & $\begin{array}{c}\text { Változás \% } \\
\text { (Bázis év } \\
\mathbf{1 9 7 0}\end{array}$ & $\begin{array}{c}\text { Mezögazdasági } \\
\text { összes terület } \\
\mathbf{( k m}^{\mathbf{2}} \mathbf{)}\end{array}$ & $\begin{array}{c}\text { Változás \% } \\
\text { (Bázis év } \\
\mathbf{1 9 7 0}\end{array}$ & $\begin{array}{c}\text { Világ } \\
\text { népessége } \\
\text { (Ezer fö) }\end{array}$ & $\begin{array}{c}\text { Változás \% } \\
\text { (Bázis év } \\
\mathbf{1 9 7 0}\end{array}$ \\
\hline $\mathbf{1 9 7 0}$ & 129721395 & & $39882 \mathbf{2 0 2}$ & & 3700578 & \\
\hline $\mathbf{1 9 8 0}$ & 129719595 & $-0,00139$ & 40673161 & 1,98 & 4458412 & 20,48 \\
\hline $\mathbf{1 9 9 0}$ & 129716836 & $-0,00351$ & 42463392 & 6,47 & 5330943 & 44,06 \\
\hline $\mathbf{2 0 0 0}$ & 129764197 & 0,03300 & 49426062 & 23,93 & 6145007 & 66,06 \\
\hline $\mathbf{2 0 1 0}$ & 129739333 & 0,01383 & 48631069 & 21,94 & 6958169 & 88,03 \\
\hline $\mathbf{2 0 1 4}$ & 129733173 & 0,00908 & 48937696 & 22,71 & 7298453 & 97,22 \\
\hline
\end{tabular}

Forrás: Saját szerkesztés, Worldbank, 2017. alapján

A Világbank 2017. évi adatai alapján látható, hogy az 1970-es évhez képest a világ összes területe 2014-re enyhe növekedést mutat, továbbá a mezőgazdasági müvelés alá vont területek nagysága közel 10 millió négyzetkilométerrel nőtt, ami mintegy $23 \%$-os növekedés. A világ népessége ezen időszakban közel kétszeresére emelkedett, amely lakosság megfelelő mennyiségü élelmiszerrel való ellátása indokolta a müvelés alá vont területek emelkedését.

Az ipari termelés növekedése és a gazdasági növekedés fellendülésének pozitív hatásai mellett azonban a káros hatások mennyisége is jelentősen megnőtt. Ezen káros hatások között említendő a klímaváltozás, amely mára bizonyítottan az emberi tevékenységre - a légkörbe bocsátott üvegházhatású gázok (ÜHG), valamint a földhasználat változására (RCPs) vezethető vissza (IPCC a, b).

Az éghajlatváltozás visszaszorítása érdekében - a globális átlaghőmérséklet-emelkedés $+2{ }^{\circ} \mathrm{C}$ alatt tartása érdekében - az Európai Unió elfogadta „Az intelligens, fenntartható és inkluzív növekedési stratégiát" (COM, 2010). Ennek célja olyan gazdasági növekedés biztosítása, ahol az oktatási, kutatási és az innovációs beruházások hatékonyak, amely támogatja az alacsony szén-dioxid-kibocsátású gazdaságra való átállást, $\mathrm{s}$ ami prioritásként kezeli a munkahelyteremtést és a szegénység csökkentését egyaránt. Az éghajlatvédelem és fenntartható energiagazdálkodás tekintetében - 2020-ra az EU egészének teljesítenie kell - az üvegházhatást okozó gázok kibocsátásának 20\%-kal történő csökkentését az 1990-es szinthez képest (vagy akár 30\%-kal, ha adottak az ehhez szükséges feltételek); a megújuló energiaforrások arányának 20\%-ra való növelését; az energiahatékonyság 20\%-kal történő javítását. A bruttó belső energiafogyasztás csökkentése, valamint az energiaimporttól való függetlenedés érdekében az EU-28 és az egyes tagországok 2020. évig vállalt megújuló energia részesedésének célértékeit és a 2014. évi teljesülésük mértékét az 1. ábra foglalja össze. 


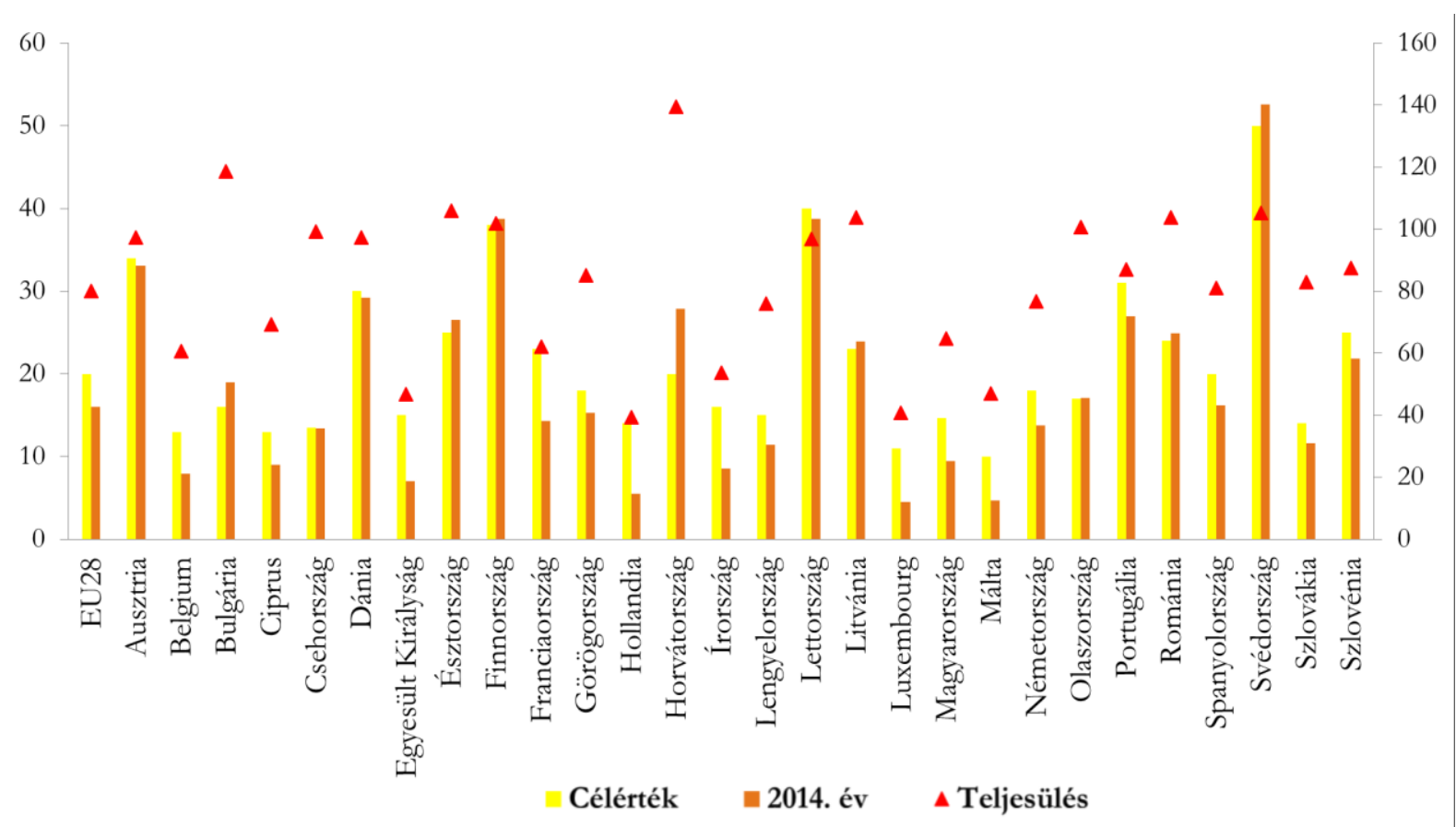

\section{1. ábra: Az EU-28, valamint tagországainak 2020. évi célértékei a megújuló energia részesedését illetően és 2014. évi teljesülésük, \%}

Forrás: Csizmásné et al., 2016

A megújuló energiaforrások részesedése az Európai Unióban 2014-ben elérte a bruttó végső energiafelhasználás 16\%-át. Az EU-28 átlagára vonatkozóan a megújuló energiaforrásokkal kapcsolatos átlagos részesedés 2013/2014-ben 15,5\%-nak felelt meg, amely lényegesen meghaladta az EU-28 tagállamaira megállapított 12,1\%-os 2013/2014-re elöirányzott arányt (COM, 2017).

A jövőben - a környezet fenntarthatósága, valamint az energia hatékonyság szempontjainak figyelembe vétele mellett - az energia fogyasztás növekedése várható. William Stanley Jevons (1835-1882) elmélete szerint az erőforrások egyre hatékonyabb felhasználása nem hozza magával az energiafogyasztás csökkentését. A Jevons-paradoxonként ismert elmélet kimondja, hogy a hatékonyság növelése nem csökkenti az eröforrások fogyasztását, sőt, gyakran annak növekedéséhez is vezethet. Az összes energiafelhasználás várható növekedésén belül azonban a megújuló energiák felhasználásának növekedése az, amellyel lehetőség nyílik napjaink egyik legaktuálisabb problémájának, az üvegházhatású gázok kibocsátásának csökkentésére is.

A fenntarthatósági megközelítés szerint szükség van az energiahatékonyságot növelő megoldások terjesztésére. Ilyen megoldásokat sorol fel az Európai Bizottság $\mathrm{K}+\mathrm{F}$ keretprogramja (Horizon 2020), amely közel 300 tématerületen támogat kutatási, fejlesztési és innovációs célú projekteket (COM 2011). Időszerü tehát a megújuló energiaforrások felhasználása, az üvegházhatású gázok kibocsátása, illetve az energiatermelés és felhasználás összefüggéseinek vizsgálata.

\section{Irodalmi áttekintés}

A Föld hőmérsékletének globális megváltozása mára bizonyított. Az ipari tevékenységek fejlődésén túlmenően az emberi tevékenységek változatossága és intenzitásuk növekedése maga után vonta az üvegházhatású gázok jelentőségteljes növekedését, mely a klímaváltozás első számú okaként ismert. A Földet elérő különböző napsugárzások mellett a Föld légköréből 
és felszínéről visszaverődő különböző energiák szintén meghatározó tényezői a klímaváltozás folyamatának.

Az emberi tevékenységek során felhasznált hagyományos energiák megújuló energiaforrásokkal történő egyre növekvő helyettesítésével az energiafüggőség csökkentése érhető el. A világ növekvő népessége és az alapanyagok iránti fokozódó kereslet hatására, az az energiahatékonyság növelésével, szintén csökkenthető az üvegházhatású gázok kibocsátása. A gazdasági mutatók, valamint az Európai Unió tagállamainak energiafogyasztása tekintetében számos hazai és nemzetközi kutatómunka - Egri - Duray (2013), Tabi (2014), Bánóczy (2013), Vida (2014), Kolasa-Wiecek (2013), Kijewska (2016), Ionescu (2014), Marinoiu (2015) - látott napvilágot.

A felsorolt irodalmak ismeretében klaszteranalízis segítségével már vizsgáltuk a megújuló energiaforrások részesedését az összes energiafelhasználásból, valamint az egyes tagállamok energiafüggősége közötti kapcsolatot (D. Németh - Székely, 2016/b). Elemzést készítettünk ugyanitt az egy före jutó üvegházhatású gázkibocsátás mértéke és a megújuló energiaforrások összes energiafelhasználásból történő részesedése között az Európai Unió tagállamait vizsgálva 2004-2014 között.

A korrelációval történt összefüggések vizsgálatát követően klaszteranalízis segítségével vizsgáltuk az EU tagállamok megújuló energiaforrásokból származó összes energia szerinti csoportosítását, a 2004. és 2014. évben (D. Németh - Székely, 2016/a). Klaszterelemzés során vizsgáltuk továbbá az egy főre jutó üvegházhatású gázkibocsátás az EU-28 tagállamok szerinti csoportosítását a 2004. és 2014. évben. Elemzéseinket kiegészítettük az egy före jutó üvegházhatású gázkibocsátás mértékének a GDP függvényében történő klaszterelemzésével az EU tagországok viszonylatában ugyanezen időszakban.

A kapcsolódó szakirodalom tanulmányozása alapján a következő megállapítások összegezhetök:

- a népességnövekedés hatására az emberi erőforrások bővülnek, a felmerülő természeti erőforrások iránti igény nő;

- a fenntartható növekedés, illetve fejlődés érdekében, a természeti erőforrások hasznosítását - a népesség növekedésének függvényében - oly módon kell megvalósítani, hogy minimális legyen a környezet minőségi és mennyiségi romlása;

- a Föld népességének növekedésével egy időben az ipari termelés, valamint az élelmiszerellátás biztosításához szükséges energiaigény növekvő tendenciát mutat;

- napjainkban az élelmiszer termeléssel és feldolgozással kapcsolatos globális primerenergia-igény (primerenergia: a természetben megtalálható nem megújuló és megújuló energiahordozók összessége, a nyers, feldolgozatlan és előkészítetlen formában elérhető energia (pl: kőszén, kőolaj, földgáz, biomassza, vízenergia, szél, napsugárzás)) kielégítése elsősorban fosszilis energiaforrások alkalmazásával kerül biztosításra. Az alacsony hatékonyság és pazarlás következtében azonban a környezet állapotának romlását okozzák;

- az alacsony szén-dioxid-kibocsátású gazdaságra való átállást olyan hatékony oktatási, kutatási és az innovációs beruházásokkal kell támogatni, melyek elősegítik a munkahelyteremtést és a szegénység csökkentését egyaránt;

- az emberi tevékenységek hatására a légkörbe kerülő káros anyagok kibocsátása nő, a klímaváltozás, mint természetes folyamat sebessége felgyorsult; 
- az éghajlatvédelem és a fenntartható energiagazdálkodás érdekében csökkenteni kell az üvegházhatást okozó gázok kibocsátását, az energiahatékonyság javítását, valamint a megújuló energiaforrások arányának növelését;

- a megújuló energiaforrások felhasználásának részaránya az összes energiafelhasználáson belül növekvő tendenciát mutat, mellyel az Európai Unió gazdasága és energiaellátási rendszere fenntarthatóbbá, biztonságosabbá és versenyképesebbé válik;

- a megújuló energiaforrások növekvő alkalmazása biztosíthatja a hagyományos energiahordozók egyre nagyobb arányú helyettesítését, valamint csökkenti a légkörbe kerülő, klímaváltozásért felelős üvegházhatású gázok kibocsátását egyaránt;

- az Európai Unió tagállamaiban a közösségi politikák révén - energiapolitika, európai éghajlatvédelmi politika - jelentős pozitív irányú elmozdulás jelenik meg a fenntarthatóság irányába. Nemzetközi viszonylatban az egyes országok vállalásai és jelenléte különböző.

A megújuló energiaforrások felhasználása, az üvegházhatású gázok kibocsátása és energiafüggőség összefüggéseinek statisztikai vizsgálati módszerrel történő vizsgálata ezért megalapozottnak tekinthető.

\section{Anyag és módszertan}

Jelen kutatásban három tényező - az egy főre jutó üvegházhatású gázkibocsátás, a megújuló energiaforrások részesedése az összes energiafelhasználásból, valamint az egyes tagállamok energiafüggősége - együttes vizsgálata került kitüzésre. Az elemzés célja bizonyítani, hogy létezik az Európai Unió tagállamai között olyan változás, amely az egy évtized alatt bekövetkezett folyamatok változásaiból, a jövőre vonatkozó változások irányvonalait, változásait jelezheti előre.

A megújuló energiaforrások felhasználása, az üvegházhatású gázok kibocsátása és az energiatermelés és felhasználás összefüggéseinek bemutatása szükségessé teszi e három gazdasági terület megismerését, valamint ezek egymásra gyakorolt hatásainak vizsgálatát, okokozati összefüggéseinek feltárását. Az adatok szekunder forrásból, illetve a KSH és Eurostat adatbázisaiból, valamint az Európai Unió ide vonatkozó forrásainak felhasználásával kerültek összeállításra.

Az elmúlt évtizedben bekövetkező és számszerűsíthető változások az EU-28 átlagának vonatkozásában klaszteranalízis segítségével kerülnek bemutatásra.

A kutatásban két klaszter távolságának képzési technikái - egyszerü lánc módszer, teljes lánc módszer, centroid módszer, medián módszer, csoportátlag módszer, Ward-módszer - közül a Ward módszert alkalmaztuk. Távolságnak a négyzetes euklideszi távolságot, vagyis az eltérésnégyzet-összeg növekedést választottuk. Ezért távolságon a későbbiekben ezt tekintjük értendőnek.

A klaszteranalízis során szükség volt a változók standardizálására, azok különböző skálán való mérése miatt.

A 2004., 2009. és a 2014. évi adatok (Eurostat, 2014; 2016/b, 2016/c) alapján háromdimenziós pontdiagram segítségével ábrázolásra került az egy főre jutó üvegházhatású gázkibocsátás, a megújuló energiaforrások összes energiafelhasználásból való részesedése, valamint az egyes tagállamok energiafüggősége közötti kapcsolat (2.a., 2.b., 2.c. ábra). 


\section{Eredmények}

A vizsgálat első lépésében a 2004. évet elemeztük, az eredményt háromdimenziós pontdiagramon ábrázoltuk (2.a. ábra).

Az egy főre jutó üvegházhatású gázkibocsátás mértéke a 2004. évben 4,99 tonna CO2e (az ÜHG kibocsátást tonna szén-dioxid egyenértékben számoljuk, ami egyben a karbonlábnyom mértékegysége is) és 31,05 tonna CO2e közötti értékben jelent meg az EU-28 tagállamaiban. Kiugróan magas értéket Luxemburg (31,05 tonna CO2e), míg rendkívül alacsony értéket Lettország $(4,99$ tonna CO2e) mutat.

A megújuló energiaforrásokból származó összes energia megoszlása a 2004. évben 0,1 és 38,7\% közötti értékben jelent meg az EU-28-ban tagállamai esetében. Kiugróan magas értéket Svédország (38,7\%), Finnország (29,2\%) és Lettország (32,8\%) mutat, míg kiugróan alacsony értéket Málta $(0,1 \%)$, valamint Luxemburg $(0,9 \%)$.

Az energiafüggőség mértéke a 2004. évben -47\% és 99,8\% közötti értéket mutat az EU-28-ban. Kiugróan magas értéket Málta (99,8\%) és Luxemburg (97,9\%), míg rendkívül alacsony értéket Dánia (-47\%) mutat. Dánia kiemelkedő értéke miatt a pontdiagramon nem szerepel.

A klaszteranalízis összevonási sémája alapján 2004-re vonatkozóan három klaszter különíthető el.

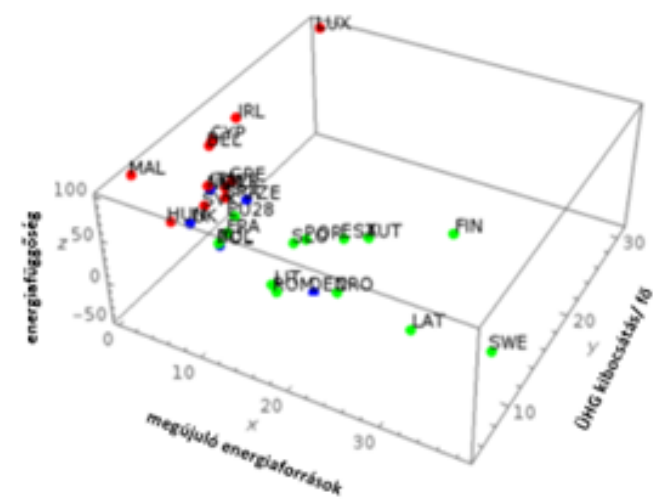

(a)

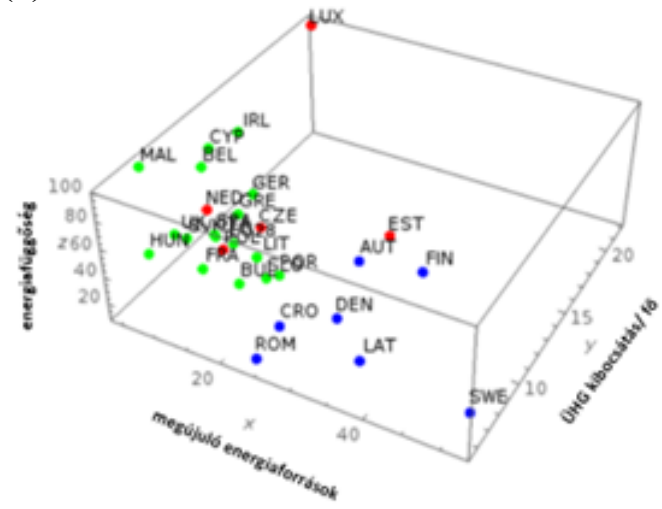

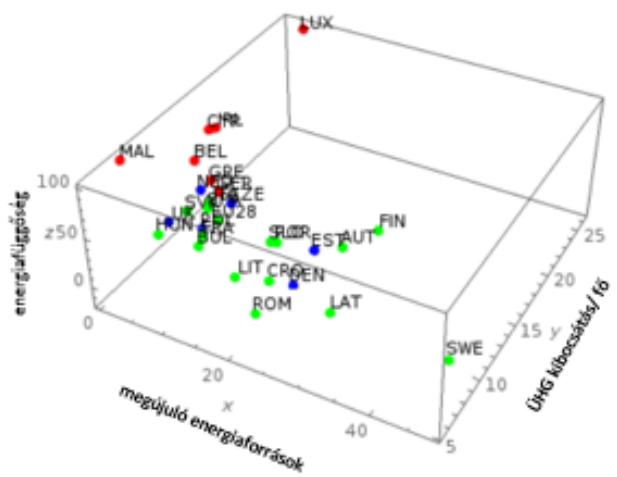

(b)

\section{Jelmagyarázat:}

Zöld: Energiafüggőséget csökkentő zöld országok

Kék: Energiafüggetlenségre törekvő, zöld országok

Piros: Erősen kitett, de zöldülő országok

(c)

2. Ábra: Az egy főre jutó üvegházhatású gázkibocsátás, a megújuló energiaforrások összes energia felhasználásból való részesedése valamint az EU tagállamainak energiafüggősége közötti kapcsolat (a) 2004-ben, (b) 2009-ben, (c) 2014-ben

Forrás: Saját szerkesztés, Eurostat, 2014; 2016/b., 2016/c. alapján 
Az első csoportot Bulgária, Franciaország, EU-28, Szlovénia, Litvánia, Románia, Horvátország, Ausztria, Portugália, Észtország, Finnország, Lettország és Svédország alkotja.

- Energiafüggőségüket tekintve 28,5 - 83,9\% között elhelyezkedő, közepesen energiafüggő országok.

- A megújuló energiaforrások összes energiafelhasználásból való részesedésük 8,5 38,7\% között valósul meg, amely a legmagasabb felhasználási arányú megújuló részesedést jelenti.

- Az egy före jutó üvegházhatású gázkibocsátás tekintetében e csoport a második legmagasabb (közepes) ÜHG-t kibocsátó országok csoportját alkotja 4,99 - 15,85 tonna $\mathrm{CO} 2 \mathrm{e}-\mathrm{kel}$.

Jellemzőik alapján ez a csoport az „Energiafüggőséget csökkentö zöld országok” kategóriájába sorolandó.

A második csoportot Csehország, Hollandia, Lengyelország, Egyesült Királyság és Dánia alkotja.

- Energiafüggőségüket tekintve -47,0 - 32,10\% között elhelyezkedő - legalacsonyabb energiafüggőséggel bíró - országok.

- A megújuló energiaforrások összes energiafelhasználásból való részesedésük 1,2 14,9\% között valósul meg, amely a második legalacsonyabb (közepes) felhasználási arányú megújuló-energiaforrás részesedést jelenti.

- Az egy före jutó üvegházhatású gázkibocsátás tekintetében e csoport a legalacsonyabb ÜHG-t kibocsátó országok csoportját alkotja 1,42 - 14,89 tonna CO2e - kel.

Jellemzöik alapján ez a csoport az „Energiafüggetlenségre törekvö, zöld gazdaságok” kategóriájába sorolandó.

A harmadik csoportban található Belgium, Ciprus, Írország, Magyarország, Szlovákia, Spanyolország, Olaszország, Németország, Görögország, Málta, Luxemburg.

- Energiafüggőségüket tekintve 60,9 - 99,8\% között elhelyezkedő - legmagasabb energiafüggőséggel bíró - országok.

- A megújuló energiaforrások összes energiafelhasználásból való részesedésük 0,1 - 8,3\% között valósul meg, amely a legalacsonyabb felhasználási arányú megújuló energiaforrás részesedést jelenti.

- Az egy före jutó üvegházhatású gázkibocsátás tekintetében e csoport a legmagasabb ÜHG-t kibocsátó országok csoportját alkotja 7,64 - 31,05 tonna CO2e - kel.

Jellemzőik alapján ez a csoport az „Erösen kitett, de zöldülö országok” kategóriájába sorolandó.

Dánia kiemelkedik a tagállamok közül, mivel a megújuló energiaforrások összes energiafelhasználásból való alacsony részesedése, valamint alacsony - 13,64 (tonna CO2e) egy főre jutó üvegházhatású gázkibocsátás mellett energiaexportőri szerepben található - $-47 \%$ os energiafüggőség mellett. Az EU-28 átlaga közepes energiafüggőséggel, magas megújuló energiaforrás részesedéssel, valamint közepes ÜHG kibocsátással az első csoport tagállamaihoz hasonlatos.

Vizsgálatunk második lépésében a 2009. évi adatokat elemezzük (2.b. ábra).

Az egy före jutó üvegházhatású gázkibocsátás mértéke a 2009. évben 5,29 tonna CO2e és 26,24 tonna CO2e közötti értékben jelent meg az EU-28-ban tagállamaiban. Kiugróan magas értéket 
Luxemburg (26,24 tonna CO2e), míg rendkívül alacsony értéket Lettország (5,29 tonna CO2e) mutat.

A megújuló energiaforrásokból származó összes energia megoszlása a 2009. évben $0,23 \%$ és 48,19\% közé esik az EU-28-ban tagállamai esetében. Kiugróan magas értéket Svédország (48,19\%), Finnország (31,43\%) és Lettország (34,32\%) mutat, míg kiugróan alacsony értéket Málta (0,23\%), valamint Luxemburg (2,94\%).

Az energiafüggőség mértéke a 2009. évben -19,7\% és 99,9\% közötti értékben jelent meg az EU-28-ban tagállamaiban. Kiugróan magas értéket Málta (99,9\%) és Luxemburg (97,5\%), míg rendkívül alacsony értéket Dánia $(-19,7 \%)$ mutat. Dánia kiemelkedő értéke miatt a pontdiagramon nem szerepel.

Az adatok további értékelése klaszteranalízissel történt, ahol az összevonási séma alapján 2009re vonatkozóan három klaszter különíthető el.

Az első csoportot Spanyolország, Olaszország, Portugália, Bulgária, Franciaország, EU-28, Magyarország, Szlovákia, Horvátország, Litvánia, Szlovénia, Románia, Ausztria, Finnország, Lettország és Svédország alkotja.

- Energiafüggőségüket tekintve 20,3 - 91,40\% között elhelyezkedő (legenergiafüggőbb) országok.

- A megújuló energiaforrások összes energiafelhasználásból való részesedésük 8,0 48,2\% között valósul meg, amely a legalacsonyabb felhasználási arányú megújuló energiaforrás-részesedést jelenti.

- Az egy főre jutó üvegházhatású gázkibocsátás tekintetében e csoport a legmagasabb ÜHG-t kibocsátó országok csoportját alkotja 6,06 - 13,0 tonna CO2e - kel.

Jellemzőik alapján ez a csoport az „Energiafüggőséget csökkentő zöld országok” kategóriájába sorolandó.

A második csoportot Lengyelország, Egyesült Királyság, Csehország, Hollandia, Dánia és Észtország alkotja.

- Energiafüggőségüket tekintve -19,7 - 36,4\% között elhelyezkedő - legkevésbé energiafüggö - legenergia-függetlenebb országok.

- A megújuló energiaforrások összes energiafelhasználásból való részesedésük 3,3 23,0\% között valósul meg, amely a legmagasabb felhasználási arányú megújuló energiaforrás-részesedést jelenti.

- Az egy fơre jutó üvegházhatású gázkibocsátás tekintetében e csoport a legalacsonyabb ÜHG-t kibocsátó országok csoportját alkotja 10,13 - 13,33 tonna CO2e - kel.

Jellemzőik alapján ez a csoport az „Energiafüggetlenségre törekvö, zöld gazdaságok” kategóriájába sorolandó.

A harmadik csoportban található Írország, Ciprus, Németország, Görögország, Belgium, Málta, Luxemburg.

- Energiafüggőségüket tekintve 99,9 - 61,0\% között elhelyezkedő - közepesen energiafüggő - országok.

- A megújuló energiaforrások összes energiafelhasználásból való részesedésük 0,2 - 9,9\% között valósul meg, amely közepes felhasználási arányú megújuló energiaforrás részesedést jelenti.

- Az egy före jutó üvegházhatású gázkibocsátás tekintetében e csoport a közepes mennyiségű ÜHG-t kibocsátó országok csoportját alkotja 8,14 - 26,24 tonna CO2e -kel. 
Jellemzőik alapján ez a csoport az „Erösen kitett, de zöldülő országok” kategóriájába sorolandó.

Dánia itt már nem alkot külön csoportot. A megújuló energiaforrások összes energiafelhasználásból való alacsony részesedése $(20 \%)$, valamint közepes $(11,89 \%)$ egy före jutó üvegházhatású gázkibocsátás mellett energiaexportőri szerepben található -19,7\%-kos energiafüggőség mellett. Az „Energiafüggetlenségre törekvő zöld gazdaságok” kategóriájába sorolandó.

Az EU-28 átlaga közepes energiafüggőséggel, magas megújuló energiaforrás részesedéssel, valamint alacsony ÜHG kibocsátással az első csoport tagállamaihoz hasonlatos.

A vizsgálat harmadik lépésében rátérünk a 2014. év elemzésére (2.c ábra).

Az egy före jutó üvegházhatású gázkibocsátás mértéke a 2014. évben 5,53 tonna CO2e és 21,88 tonna CO2e értékek között változik az EU-28 tagállamaiban. Kiugróan magas értéket Luxemburg (21,88 tonna CO2e), míg rendkívül alacsony Románia (5,53 tonna CO2e), Magyarország (5,85 tonna CO2e) és Svédország (5,88 tonna CO2e) esetében tapasztaltunk.

A megújuló energiaforrásokból származó összes energia megoszlása a 2014. évben 4,54 és 52,6\% közötti értékben jelent meg az EU-28-ban tagállamai esetében. Kiugróan magas értéket Svédország (52,6\%), Finnország (38,69\%) és Lettország (38,65\%), kiugróan alacsony értéket Málta (4,71\%) valamint Luxemburg (4,54\%) mutat.

Az energiafüggőség mértéke a 2014. évben 8,9\% és 97,7\% közötti értékben jelent meg az EU28-ban tagállamaiban. Kiugróan magas érték Málta (97,7\%) és Luxemburg (96,6\%), míg rendkívül alacsony érték Észtország $(8,9 \%)$ és Dánia $(12,8 \%)$ esetében látható.

Az adatok további értékelése klaszteranalízissel történt, ahol az összevonási séma alapján 2014re vonatkozóan három klaszter különíthető el.

Az első csoportot Spanyolország, Olaszország, Litvánia, Portugália, Görögország, Németország, Bulgária, Szlovénia, EU-28, Franciaország, Magyarország, Szlovákia, Egyesült Királyság, Belgium, Ciprus, Írország és Málta alkotja.

- Energiafüggőségüket tekintve 34,5 - 97,7\% között elhelyezkedő - magasan energiafüggő - országok.

- A megújuló energiaforrások összes energiafelhasználásból való részesedésük 4,7 27,0\% között valósul meg, amely a közepes felhasználási arányú megújuló energiaforrás-részesedést jelenti.

- Az egy före jutó üvegházhatású gázkibocsátás tekintetében e csoport a közepes ÜHG-t kibocsátó országok csoportját alkotja 5,85 - 13,14 tonna CO2e - kel.

Jellemzőik alapján ez a csoport az „Energiafüggőséget csökkentö zöld országok” kategóriájába sorolandó.

A második csoportot Csehország, Lengyelország, Hollandia, Észtország és Luxemburg alkotja.

- Energiafüggőségüket tekintve 8,9 - 96,6\% között elhelyezkedő közepesen energiafüggő országok.

- A megújuló energiaforrások összes energiafelhasználásból való részesedésük 4,5 26,5\% között valósul meg, amely a legalacsonyabb felhasználási arányú megújuló energiaforrás-részesedést jelenti. 
- Az egy főre jutó üvegházhatású gázkibocsátás tekintetében e csoport a legmagasabb ÜHG-t kibocsátó országok csoportját alkotja 10,05 - 21,88 tonna CO2e -kel.

Jellemzőik alapján ez a csoport az „Erösen kitett, de zöldülö országok” kategóriájába sorolandó.

A harmadik csoportban található Ausztria, Finnország, Horvátország, Lettország, Dánia, Románia és Svédország.

- Energiafüggőségüket tekintve 12,8 - 65,9\% között elhelyezkedő legkevésbé energiafüggő országok.

- A megújuló energiaforrások összes energiafelhasználásból való részesedésük 13,8 52,6\% között valósul meg, amely a legmagasabb felhasználási arányú megújuló energiaforrás-részesedést jelenti.

- Az egy fơre jutó üvegházhatású gázkibocsátás tekintetében e csoport a legalacsonyabb ÜHG-t kibocsátó országok csoportját alkotja 5,53 - 11,45 tonna CO2e -kel.

Jellemzőik alapján ez a csoport az „Energiafüggetlenségre törekvö, zöld gazdaságok” kategóriájába sorolandó.

Az EU-28 átlaga magas energiafüggőséggel, közepes megújuló energiaforrás részesedéssel, valamint közepes ÜHG kibocsátással az első csoport tagállamaihoz hasonlatos.

Dánia 2014-re elvesztette energiaexportőri szerepét, energiafüggősége alacsony, megújuló energiaforrás részesedése magas, míg ÜHG kibocsátása alacsony értéket mutat. 2014-ben Dánia világelső lett a szélenergiában, mivel a teljes energiakapacitásának immáron a 39,1 százalékát a szélturbináinak köszönheti. Ezzel az eredménnyel valóban megvan a lehetősége arra, hogy öt éven belül, 2020-ra a szélenergiából nyert kapacitás elérje az általuk vállalt 50 százalékot (Greenfo, 2015), s hogy a tervek szerint 2050-re fosszilis tüzelőanyag mentes állammá váljon.

Angliában a szélből nyert energia 2014-ben már a háztartások negyedét képes volt árammal ellátni, míg egy évvel korábban 2013-ban csupán a 15 százalékát adta a teljes állami kapacitásnak (Greenfo, 2015).

A vizsgált - 2004. 2009. 2014. - években történt változások alapján a következő összegzés tehető.

- Az „Erösen kitett, de zöldülő országok” kategóriájából az „Energiafüggőséget csökkentö, zöld országok” kategóriájába csoportot váltott: Belgium, Németország, Írország, Görögország, Spanyolország, Olaszország, Ciprus, Magyarország, Málta, Szlovákia.

- Az „Energiafüggetlenségre törekvő zöld gazdaságok” kategóriájából az „Erösen kitett, de zöldülö országok" kategóriájába csoportot váltott: Csehország, Hollandia, Lengyelország.

- Az „Energiafüggőséget csökkentő, zöld országok” kategóriájából az „Energiafuiggetlenségre törekvö zöld gazdaságok” kategóriájába, majd onnan az „Erősen kitett, de zöldülő országok” kategóriájába váltott csoportot: Észtország.

- Az „Energiafüggőséget csökkentö, zöld országok” kategóriájából az „Energiafüggetlenségre törekvö zöld gazdaságok” kategóriájába váltott csoportot: Horvátország, Lettország, Ausztria, Románia, Finnország, Svédország.

- Az „Energiafüggetlenségre törekvő zöld gazdaságok” kategóriájából az „Energiafüggöséget csökkentö, zöld országok” kategóriájába csoportot váltott: Egyesült Királyság. 
Nem történt csoportváltás Franciaország, Litvánia, Luxemburg, Portugália, Szlovénia, esetében.

Összefoglalva, három csoport képzésére van lehetőség az egy före jutó üvegházhatású gázkibocsátás valamint a megújuló energiaforrások részesedése az összes energiafelhasználásból és az egyes tagállamok energiafüggősége közötti vizsgálat esetében. Megemlítjük, hogy a kutatás során az összes lehetséges kétváltozós lineáris regressziós modell is elemzésre, kipróbálásra került. Az elemzések során kiderült, hogy egyik modell (két változó független, a harmadik pedig függő) sem volt releváns, így ezeket nem is közöltük.

A vizsgált évek változásainak folyamatát elemezve, az eredmények táblázatba rendezése során kialakult egy, a csoportok közötti átmenetet, illetve folyamatos fejlődést mutató rendszer, amelyet az „Energiafüggetlenségre törekvő és zöldülő ország kialakításának fázisai” névvel határoztunk meg (2. táblázat).

2. Táblázat: az EU tagállamainak csoportok közötti mozgása, a vizsgált - 2004., 2009., 2014. - években

\begin{tabular}{|c|c|c|c|c|c|c|c|c|c|c|}
\hline \multirow[b]{2}{*}{ ország } & \multirow[b]{2}{*}{ rövidítés } & \multicolumn{3}{|c|}{2004} & \multicolumn{3}{|c|}{2009} & \multicolumn{3}{|c|}{2014} \\
\hline & & I. & II. & III. & I. & II. & III. & I. & II. & III. \\
\hline EU28 & EU28 & & $X$ & & & $\mathrm{X}$ & & & $\mathrm{X}$ & \\
\hline Belgium & BEL & $\mathrm{X}$ & & & $\mathrm{X}$ & & & & $\mathrm{X}$ & \\
\hline Bulgária & BUL & & $X$ & & & $\mathrm{X}$ & & & $\mathrm{X}$ & \\
\hline Csehország & CZE & & & $X$ & & & $\mathrm{X}$ & $\mathrm{X}$ & & \\
\hline Dánia & DEN & & & $X$ & & & $\mathrm{X}$ & & & $\mathrm{X}$ \\
\hline Németország & GER & $\mathrm{X}$ & & & $\mathrm{X}$ & & & & $\mathrm{X}$ & \\
\hline Észtország & EST & & $\mathrm{X}$ & & & & $X$ & $\mathrm{X}$ & & \\
\hline Írország & IRL & $\mathrm{X}$ & & & $\mathrm{X}$ & & & & $\mathrm{X}$ & \\
\hline Görögország & GRE & $\mathrm{X}$ & & & $\mathrm{X}$ & & & & $\mathrm{X}$ & \\
\hline Spanyolország & SPA & $\mathrm{X}$ & & & & $X$ & & & $\mathrm{X}$ & \\
\hline Franciaország & FRA & & $X$ & & & $\mathrm{X}$ & & & $\mathrm{X}$ & \\
\hline Horvátország & CRO & & $\mathrm{X}$ & & & $\mathrm{X}$ & & & & $\mathrm{X}$ \\
\hline Olaszország & ITA & $\mathrm{X}$ & & & & $\mathrm{X}$ & & & $\mathrm{X}$ & \\
\hline Ciprus & CYP & $\mathrm{X}$ & & & $\mathrm{X}$ & & & & $\mathrm{X}$ & \\
\hline Lettország & LAT & & $\mathrm{X}$ & & & $\mathrm{X}$ & & & & $\mathrm{X}$ \\
\hline Litvánia & LIT & & $\mathrm{X}$ & & & $\mathrm{X}$ & & & $\mathrm{X}$ & \\
\hline Luxemburg & LUX & $\mathrm{X}$ & & & $\mathrm{X}$ & & & $X$ & & \\
\hline Magyarország & HUN & $\mathrm{X}$ & & & & $\mathrm{X}$ & & & $\mathrm{X}$ & \\
\hline Málta & MAL & $\mathrm{X}$ & & & $\mathrm{X}$ & & & & $\mathrm{X}$ & \\
\hline Hollandia & NED & & & $\mathrm{X}$ & & & $\mathrm{X}$ & $\mathrm{X}$ & & \\
\hline Ausztria & AUT & & $X$ & & & $\mathrm{X}$ & & & & $\mathrm{X}$ \\
\hline Lengyelország & POL & & & $\mathrm{X}$ & & & $\mathrm{X}$ & $\mathrm{X}$ & & \\
\hline Portugália & POR & & $\mathrm{X}$ & & & $\mathrm{X}$ & & & $\mathrm{X}$ & \\
\hline Románia & ROM & & $\mathrm{X}$ & & & $\mathrm{X}$ & & & & $\mathrm{X}$ \\
\hline Szlovénia & SLO & & $\mathrm{X}$ & & & $\mathrm{X}$ & & & $\mathrm{X}$ & \\
\hline Szlovákia & SVK & $\mathrm{X}$ & & & & $\mathrm{X}$ & & & $\mathrm{X}$ & \\
\hline Finnország & FIN & & $\mathrm{X}$ & & & $\mathrm{X}$ & & & & $\mathrm{X}$ \\
\hline Svédország & SWE & & $\mathrm{X}$ & & & $\mathrm{X}$ & & & & $\mathrm{X}$ \\
\hline Egyesült Királyság & UK & & & $X$ & & & $\mathrm{X}$ & & $\mathrm{X}$ & \\
\hline
\end{tabular}

Jelmagyarázat:

I. Erősen kitett, de zöldülő országok

II. Energiafüggőséget csökkentő zöld országok

III. Energiafüggetlenségre törekvő, zöld országok

Forrás: Saját szerkesztés 
Az Erősen energiafüggő országok közé tartoznak azok az országok, amelyek energiaszükségletük jelentős részét részben saját hagyományos energiaforrásból, részben saját termelésű megújuló energiaforrásból sem képesek biztosítani állampolgáraik részére, ezért jelentős energiaimportra szorulnak.

Az Erösen kitett, de zöldülő országok, melyek jelentős erőfeszítéseket tesznek energiafüggőségük csökkentésére, valamint megújuló energiaforrásaik fejlesztésére, úgymint Írország, Görögország, Ciprus.

$\mathrm{Az}$ Energiafüggöséget csökkentő zöld országok azok, melyek céljaként szerepel energiaellátásuk saját energiaforrásból történő kielégítése, melyhez jelentős beruházásokat, illetve fejlesztéseket eszközölnek, úgymint Németország, Franciaország, Olaszország, Spanyolország Észtország, Portugália és Magyarország.

Az Energiafüggetlenségre törekvő, zöld országok kategóriáját alkotó országok az általában versenyképes gazdasággal rendelkező országok, ahol a fenntarthatóság és a káros anyagok kibocsátása elleni aktív tevékenység egyaránt gazdasági és társadalmi érdek, pl: Dánia, Lettország, Finnország, Svédország.

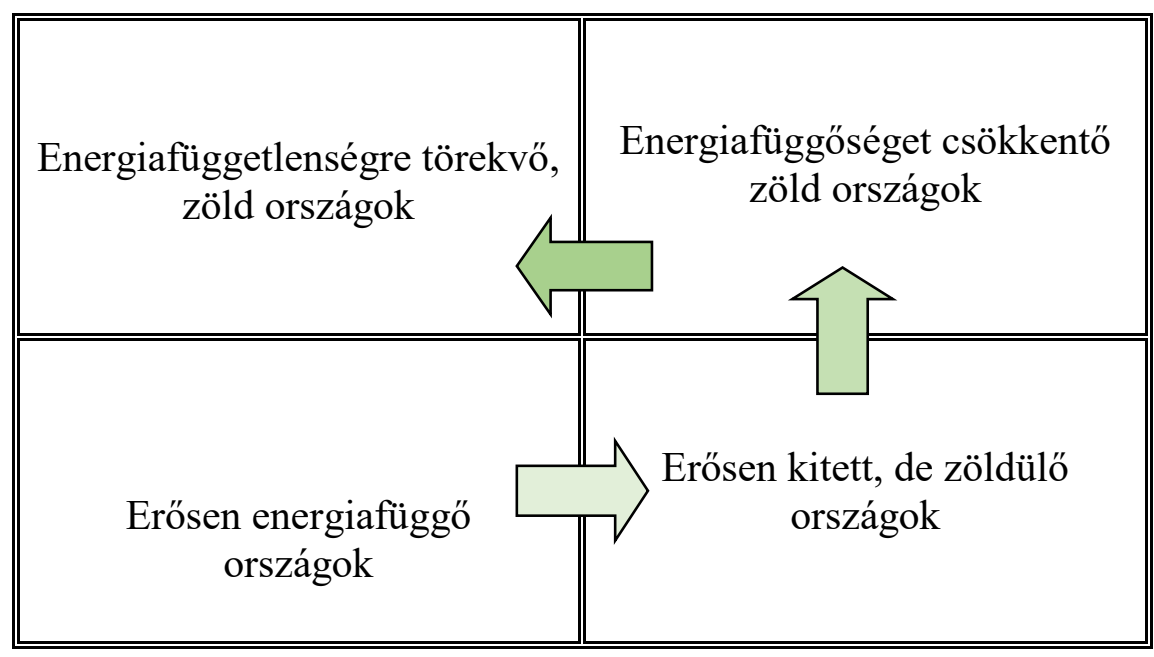

3. ábra: Energiafüggetlenségre törekvő és zöldülő ország kialakításának fázisai Forrás: Saját szerkesztés

Kiemelkedő teljesítményt mutat Lettország, amely az Energiafüggőséget csökkentö-, illetve az Energiafüggetlenségre törekvö, zöld országok kategóriájában tart stabil pozíciót.

Az Erősen energiafüggő országok kategóriájába jelen vizsgálatban ország nem került, ezért az Erősen energiafüggő országok csoportja itt nem releváns.

A megújuló energiaforrások részesedése az összes energiafelhasználásból, és az egyes tagállamok energiafüggősége közötti vizsgálat esetében például mindhárom vizsgált évben 2004, 2009, 2014 - az Energiafüggőséget csökkentő, zöld országok csoportja meghatározó volt.

\section{Következtetések}

Elemzésünk során bebizonyosodott, hogy a vizsgált országok évről évre egyre jobban törekednek az egyre energiahatékonyabb és energiafüggetlenebb gyakorlat megvalósítására. Ennek bizonyítéka az évről évre növekvő, 2014-re 16,1\%-os megújuló energia arány elérése a bruttó végső energiafogyasztásban, az EU-28-ban. Bár a tagországok között nagy szóródás 
tapasztalható, egyes országokban a megújuló energia arány közelíti, illetve eléri a 30\%-ot Dánia $(29,3)$, Lettország $(38,7)$, Ausztria $(32,8)$-, máshol a 40\%-ot - Finnország $(38,7)$-, valamint, meghaladja az 50\%-ot - Svédország (52,5) esetében. 2015-re ez a tendencia folytatódott, bár a felsorolt országok élmezőnyébe új szereplő nem került. Ezzel párhuzamosan csökkenő tendencia figyelhető meg a primer-energia termelésben. Ennek oka a nyersanyagkészletek kimerülése, valamint a termelők ítélete a korlátozottan rendelkezésre álló eröforrások kitermelésére vonatkozóan. A 2014. évi primer-energia termelést adó különböző energiaforrások közül, részarányát tekintve az atomenergia volt a legjelentősebb $(29,3 \%)$ az EU-28-ban, kiemelve Franciaország (82,8\%), Belgium (71,2\%) és Szlovákia $(64,1 \%)$ termelését. Ezzel szemben Németország például összes atomreaktora bezárását tervezi. Az egy före jutó ÜHG kibocsátás tekintetében az EU-28 átlagában csökkenés tapasztalható. Ezt támogatják a nemzetközi megállapodások, valamint az Európai Uniós és hazai intézkedések egyaránt. A 2020-ra vállalt célkitüzéseken (COM, 2010) túlmenően 2014. októberében megállapodás született az Európai Unió 2030-as éghajlat- és energiapolitikai célkitüzéseiről (COM, 2014) is. A 2030-ig szóló keret olyan új célokat és intézkedéseket fogalmaz meg, amelyek arra irányulnak, hogy mind az EU gazdasága mind az energiaellátási rendszere fenntarthatóbbá, biztonságosabbá és versenyképesebbé váljon. Legfontosabb célkiüzései között szerepel: 2030-ra az 1990-es szinthez képest legalább 40\%-kal csökkenteni kell az üvegházhatást okozó gázok kibocsátását az Unióban; a felhasznált energia legalább 27\%-a megújuló energiaforrásból származzon; az energiahatékonyság 27\%-os javítása a 2030-ra előre jelzett energiafogyasztáshoz képest.

Kutatásunk során bizonyítást nyert, hogy a vizsgált három tényező alakulásában bekövetkezett változások előre jeleznek egy, a jövőben várható, a fenntarthatóság irányába történő elmozdulást. A három tényező együttes mozgása ellensúlyozza az egyes tagországonként különböző mértékben eltérő hiányosságokat. Az Erősen energiafüggő országok kategóriájába 2014-re tagország nem került, amely a megújuló energiaforrások felhasználása, az üvegházhatású gázok kibocsátása és az energiafelhasználás arányrendszerében történő növekedést, az egyes tagállamok eltérő célkitüzései irányába történő elörehaladást mutatja. Összehasonlító elemzésekkel bemutattuk a különbözőségeket, egyenlőtlenségeket az EU eltérő jellemzőkkel rendelkező - tagországaiban, melyek befolyásolhatják a megújuló energiaforrások alkalmazásával, illetve technológiai fejlesztésének lehetőségeivel, valamint a fenntartható gazdasági fejlődéssel foglalkozó döntéshozókat.

\section{Irodalomjegyzék}

1. Bánóczy E. (2013): Megújuló energiaforrások gazdaságossági elemzése az épületenergetikában Miskolci Egyetem, Gazdaságtudományi Kar, Gazdálkodástani Intézet

2. COM (2010) 2020: A bizottság Közleménye, Európa 2020, Az intelligens, fenntartható és inkluzív növekedés stratégiája, Brüsszel, 2010.3.3. http://ec.europa.eu/eu2020/pdf/1_HU_ACT_part1_v1.pdf Utolsó letöltés: 2016.09.15.

3. COM (2011) 808: A Bizottság közleménye az Európai Parlamentnek, a Tanácsnak, az Európai Gazdasági és Szociális Bizottságnak és a Régiók Bizottságának a „Horizont 2020” kutatási és innovációs keretprogramról http://eur-lex.europa.eu/legalcontent/HU/TXT/PDF/?uri=CELEX:52011DC0808\&from=HU Letöltve:2018.04.26.

4. COM (2014) 15: A Bizottság közleménye: „Éghajlat- és energiapolitikai keret a 20202030-as időszakra” - Brüsszel, 2014.1.22. COM (2014) 15 final Letöltve:2016.09.01. http://eur-lex.europa.eu/legal-

content/HU/TXT/PDF/?uri=CELEX:52014DC0015\&from=HU 
5. COM (2017) 57: A Bizottság közleménye az Európai Parlamentnek, a Tanácsnak, az Európai Gazdasági és Szociális Bizottságnak és a Régiók Bizottságának Eredményjelentés a megújuló energiákról Brüsszel, 2017.2.1. Letöltve: 2017.05.01.

6. D. Németh Zs., Székely L. (2016a): Megújuló energiaforrások és a fenntartható fejlődés -Nemzetközi Tudományos Konferencia. Renewable energy resources and the sustainable development - International Scientific Conference. LVIII. Georgikon Napok, Keszthely, 2016. szeptember 29-30. Alternatív energiagazdálkodás szekció pp: (81-91 ISBN 978-963-9639-84-3)

7. D. Németh Zs., Székely L. (2016b): Megújuló energiaforrások és a CO2 kibocsátás kapcsolata a 2020-as célok eléréséhez - Nemzetközi Tudományos Konferencia. Renewable energy resources connection with the $\mathrm{CO} 2$ emission to reach the aims of 2020 - International Scientific Conference. LVIII. Georgikon Napok, Keszthely, 2016. szeptember 29-30. Alternatív energiagazdálkodás szekció pp: 69-80 (ISBN 978963-9639-84-3)

8. Csizmásiné Tóth J., Poór J., Hollósy Zs. (2016): A megújuló energiafelhasználás nemzetközi és magyar vonatkozásai - politikák, vállalások, tendenciák - , Renewable energy consumption- World, EU, Hungary - policies, targets, trends - LVIII. Georgikon Napok, Keszthely, 2016. Szeptember 29-30. Alternatív energiagazdálkodás szekció pp: 58-68 (ISBN 978-963-9639-84-3)

9. Egri Z. - Duray B., 2013: Magyarország az európai zöldgazdaság rendszerében, főbb társadalmi-gazdasági összefüggések, Régiók fejlesztése 2013/2 konferencia TÁMOP4.2.2.A-11/1/KONV-2012-0015 „Alapkutatás fejlesztés a Szent István Egyetem Pirolízis Technológia Kutatóközpontjában" http://pirolizis.szie.hu/content/r-gi-kfejleszt-se-20132-konferencia-kiadv-nyban-megjelent-publik-ci-k Letöltve: 2016.09.15.

10. EUROSTAT (2014): Üvegházhatásúgáz-kibocsátás szektoronként, (tsdcc210), Letöltve: 2017.01.03. http://ec.europa.eu/eurostat/tgm/refreshTableAction.do?tab=table\&plugin=1\&pcode $=$ tsdcc $210 \&$ language $=$ en

11. EUROSTAT, (2016b): Letöltve: 2016.09.15. http://ec.europa.eu/eurostat/statisticsexplained/index.php/File:Energy_dependency_by_fuel,_EU-28,_1990-1998-20062014,_ktoe_new.png

12. EUROSTAT, (2016c): Letöltve: 2016.09.15. http://ec.europa.eu/eurostat/statisticsexplained/pdfscache/1216.pdf

13. GREENFO, (2015): http://greenfo.hu/hirek/2015/01/12/szelenergia-vilagrekorddaniaban Letöltve: 2016. 08. 22.

14. Ionescu R.-V. (2014): ,Regional Environment Disparities and Europe 2020 Strategy’s Goals" Performance and Risks in the European Economy EIRP Proceedings, Vol 9 (2014) Letöltve: 2017.06.06. http://www.proceedings.univdanubius.ro/index.php/eirp/article/view/1507

15. IPCCa, (2014): Climate Change 2014, Sythesis Report, Observed Changes and theit causes, $\quad$ p. $40 . \quad$ https://www.ipcc.ch/pdf/assessmentreport/ar5/syr/AR5_SYR_FINAL_All_Topics.pdf Letöltve: 2018.04.26.

16. IPCCb, (2014): Climate Change 2014, Sythesis Report, Future Climate, Changes, Risk and Impacts, (RCPs), p. 57. https://www.ipcc.ch/pdf/assessmentreport/ar5/syr/AR5_SYR_FINAL_All_Topics.pdf Letöltve: 2018.04.26.

17. Jevons, W. S.: The Coal Question, London, Macmillan and Co., 1866. http://www.econlib.org/library/YPDBooks/Jevons/jvnCQ.html Letöltve: 2017.12.12.

18. Kijewska A. (2016): Analyses of greenhouse gas emissions in the European Union member states with the use of an agglomeration algorithm Journal of Sustainable 
$\begin{array}{lllll}\text { Mining } & 15 & \text { (2016) } & \text { 133-142 }\end{array}$ http://www.sciencedirect.com/science/article/pii/S2300396016300799

19. Kolasa-Wiecek A. (2013): The use of cluster analysis in the classification of similarities in variables associated with agricultural greenhouse gases emissions in OECD countries WIEŚ I ROLNICTWO, NR 1 (158) 2013 Letöltve: 2017.06.07. http://ageconsearch.umn.edu/bitstream/231628/2/WiR_1-2013\%2059-66.pdf

20. Marinoiu C. (2015): Classification of the EU countries in terms of the evolution of the GHG indicator using cluster analysis, Annals of the „Constantin Brâncuşi” University of Târgu Jiu, Economy Series, Issue 3/2015. Letöltve: 2017.06.06. http://www.utgjiu.ro/revista/ec/pdf/2015-03/06_Marinoiu\%20Cristian.pdf

21. Tabi A. (2014): A társadalmi tényezők szerepe az alacsony karbon-kibocsátású átalakulás felé, Doktori (PhD) értekezés, Budapesti Corvinus Egyetem

22. Vida A. (2014): A bioüzemanyagok előállításának és alkalmazásának gazdasági értékelése Magyarországon Doktori (PhD) értekezés, Szent István Egyetem, Gödöllő

23. Várallyay Gy. (2010): A talaj, mint víztározó; talajszárazodás „Klíma-21” füzetek. 126 p. Budapest, AKAPRINT KFT., 2010. 59.sz./2010 (3-25. p.) MTA KSZI Klímavédelmi Kutatások Koordinációs Iroda (ISSN 1789-428X)

24. World Bank (2017): http://data.worldbank.org/indicator/AG.LND.AGRI.K2 Letöltve: 2017.07.11. 